\title{
Lamproite-orangeite transition in 159 Ma dykes of Dronning Maud Land, Antarctica?
}

\author{
K.R. Ilona Romu ${ }^{1}$, Arto V. Luttinen ${ }^{1}$, and Hugh E. O'Brien ${ }^{2}$ \\ ${ }^{1}$ Department of Geology, University of Helsinki, Finland \\ ${ }^{2}$ Geological Survey of Finland,Espoo, Finland
}

\section{Introduction}

Vestfjella 159 Ma ultrapotassic dyke swarm (VUDS) in western Dronning Maud Land (WDML), Antarctica, comprises a suite of dykes at Kjakebeinet $\left(73^{\circ} 47^{\prime} \mathrm{S}\right.$ $\left.014^{\circ} 51^{\prime} \mathrm{W}\right)$ and two discrete dykes at Muren ( $73^{\circ} 44^{\prime} \mathrm{S}$ $015^{\circ} 00^{\prime} \mathrm{W}$ ) (Fig. 1, Table 1). A minor suite was first discovered by the Finnish Antarctic Research Programme (FINNARP) expedition in 1998 and, subsequently, Luttinen et al. (2002) referred to these rocks as lamproites and pointed out a geochemical similarity to diopside madupitic lamproites from Leucite Hills, USA, and affinities to spatially and temporally related orangeites (group II kimberlites, Mitchell, 1995) of southern Africa (Fig.1). Here we report on the distribution, field appearance, and the mineralogical and geochemical traits of VUDS based on detailed mapping of nunataks during austral summer 2007.

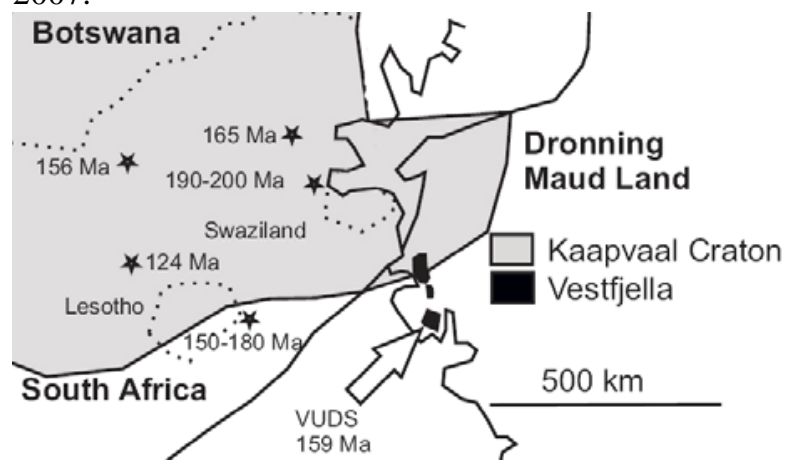

Fig. 1. Vestfjella ultrapotassic dyke swarm (VUDS), tectonic setting prior to Jurassic detachment at $\sim 200$ Ma. Stars indicate group II kimberlite fields of South Africa (cf. Mitchell 1995). Reconstruction of Gondwana after Lawver, Gacahan \& Coffin (1992).

\section{Regional geology}

WDML records a geological history closely associated with southern Africa, from Archean to Mesozoic. The Precambrian basement of WDML comprises an Archean craton and a Proterozoic mobile belt that represent extensions of the Kaapvaal craton and the Natal belt of southern Africa, respectively (e.g. Groenewald et al., 1995, Moyes et al., 1995, Jacobs et al.,1996). Aeromagnetic studies imply that the 1000
Ma Grenvillean-age suture may be located beneath Vestfjella (Corner, 1994). Adjacent to the rifted continental margin, the exposed bedrock of Vestfjella is composed almost exclusively of Jurassic flood basalts belonging to the Karoo large igenous province. The basalts and the related dolerite dykes and gabbros have been correlated with the 180 Ma mafic igneous rocks of southern Africa (cf. Luttinen \& Furnes, 2000, Vuori \& Luttinen, 2003, Riley et al., 2005). Recent geochronological studies imply episodic intrusive events of basaltic magmas continued from $180 \mathrm{Ma}$ until $165 \mathrm{Ma}$, possibly as late as $150 \mathrm{Ma}$ (Matti Kurhila, pers comm. 2008), and may have been associated with previously dated hydrothermal events at 139 Ma and 150 Ma (Zhang et al., 2003). Numerous normal faults indicate post-volcanic tectonic activity that may have been associated with dyke emplacement. The ultrapotassic, mica-rich dykes were emplaced at $159 \mathrm{Ma}$, cross-cut Karoo flood basalts and related dykes (Fig. 2), and represent one of the last intrusive events in the area. Crustal xenoliths in the ultrapotassic dykes record emplacement through Grenvillian ( Kibaran) Maud Belt rocks (Romu \& Luttinen, 2007).

\section{Field relationships}

\begin{tabular}{|c|c|c|c|c|c|c|c|}
\hline & Dyke & Location & Lat (o '") & Lon (o '") & Strike & Dip dir. & Dip \\
\hline D 01 & KRRO-07-33 & Kjakebeinet & 734747.5 & 0145131.6 & 340.5 & 80.5 & 80 \\
\hline \multirow[t]{2}{*}{ D 02} & AL/KB1-03 & Kjakebeinet & 734744.5 & 0145430.1 & \multicolumn{3}{|c|}{$\begin{array}{l}\text { Boulders, probably } \\
\text { weathered in sifu }\end{array}$} \\
\hline & AL/KB6-98 & & 734702.5 & 0145221.5 & 352.5 & 80.5 & 82 \\
\hline \multirow[t]{2}{*}{ D 03} & AL/KB8-98 & Kjakebeinet & 734700.6 & 0145223.8 & 350.5 & 80.5 & 74 \\
\hline & KRRO-07-28 & & 734701.9 & 0145222.5 & 355.5 & 265.5 & 86 \\
\hline 04 & KRRO-07-25 & Kjakebeinet & 734 & 29.1 & 40.5 & 70.5 & 80 \\
\hline 05 & AL/KB21-98 & Kjakebeinet & 734754.5 & 123.1 & 354.5 & 84.5 & 84 \\
\hline 06 & AL/KB1-31-98 & Kjakebeinet & 7347 & 01 & Boulder & & \\
\hline 07 & KRRO-07-36 & Kjakebeinet & 734 & 04.8 & 330.5 & 60.5 & 82 \\
\hline D 08 & KRRO-07-11 & Kjakebeinet & 734 & 014 & 350.5 & 80.5 & 83 \\
\hline \multirow[t]{2}{*}{ D 09} & KRRO-07-19 & Kjakebeinet & 7347 & 014 & 350.5 & 80.5 & 88 \\
\hline & KRRO-07-20 & & 734756.4 & 36.7 & 350.5 & 80.5 & 80 \\
\hline \multirow[t]{2}{*}{ D 10} & KRRO-07-21 & Kjakebeinet & 734756.2 & 0145538.0 & 350.5 & 80.5 & 80 \\
\hline & KRRO-07-22 & & 734756.2 & 0145538.6 & 350.5 & 80.5 & 82 \\
\hline 11 & KRRO-07-45 & West Muren & 734 & 015 & 0.5 & 90.5 & 86 \\
\hline 12 & KRRO-08-89 & East Muren & 734411.8 & 0145833.0 & 336.5 & 76.5 & 82 \\
\hline
\end{tabular}

Table 1. Dyke (D01-D12) locations; strikes and dip directions (Dip. dir) corrected for magnetic declination by factor $9.5^{\circ}$.

Twelve broadly N-S trending dykes and small groups of dykes (Table 1) have been discovered as a result of detailed mapping of nunataks Kjakebeinet $\left(\sim 20 \mathrm{~km}^{2}\right)$ and Muren $\left(\sim 7 \mathrm{~km}^{2}\right)$ in southern Vestfjella. The steeply 
dipping (74-88 deg ESE) dykes are relatively narrow ( 0.3 to $2.4 \mathrm{~m}$, mainly $<1 \mathrm{~m}$ ) and crop out as individual dykes or small groups of 3 (Table 1). Mica rich dykes have not been reported outside this area, but detailed mapping of South Vestfjella has not been completed. Individual dykes cannot be laterally or vertically traced for more than ca. $50 \mathrm{~m}$. Most of the dykes have disctictively zoned appearance and fenitized margins are common. Two relatively wide dykes (D 01 \& 02) contain abundant xenoliths of granitoids and gneisses show well-defined strike-parallel zonation.

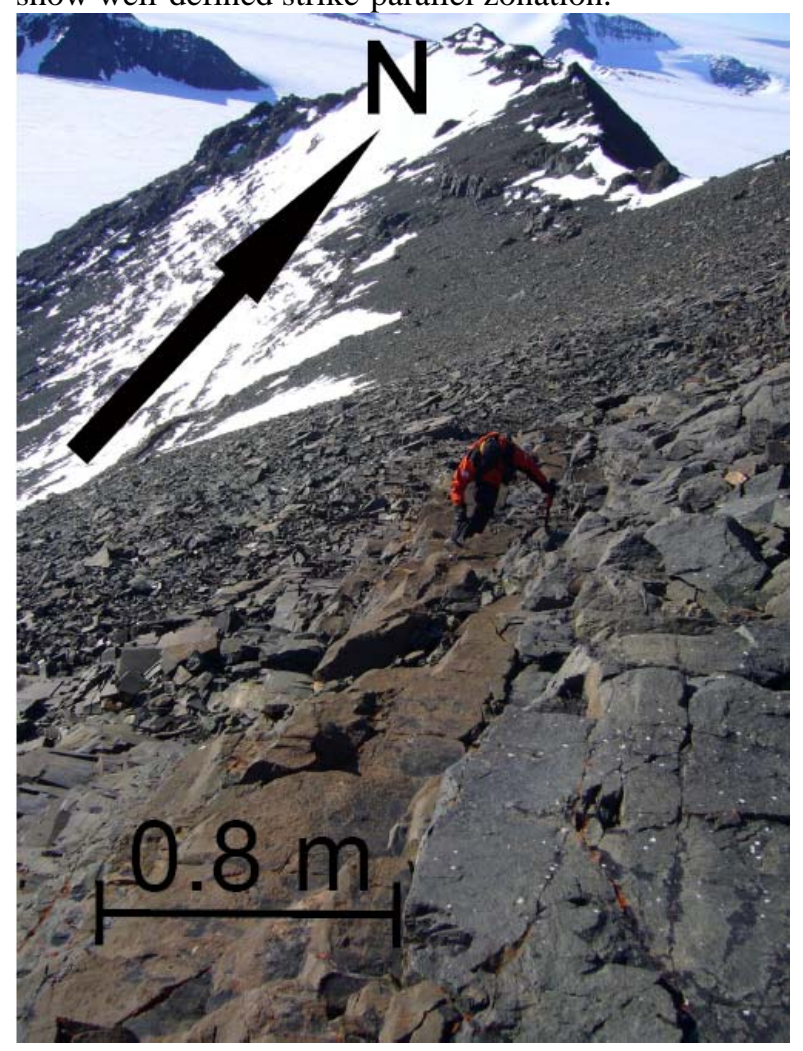

Fig. 2. Dyke D 03 cross-cuts basalt lavas and is closely associated with basalt and diabase dykes at the summit of Kjakebeinet.

\section{Compositional characteristics}

Field appearance and mineralogy

All the dykes are inequigranular, heterogenous and show strike-parallel variation in grain size and/or composition and distribution of macrocrysts. The dykes have a fine-grained groundmass, show variation in texture, amount and type of macrocrysts and xenolithic fragments, as well as phenocryst \pm macrocryst to groundmass ratio. Phenocrystal and microphenocrystal phases commonly observed in the dykes are titanian aluminous phlogopite (2-8 wt-\% $\mathrm{TiO}_{2}, 8-16$ wt-\% $\mathrm{Al}_{2} \mathrm{O}_{3}$ ); low $\mathrm{Al}$ and low Ti diopside (1-3 wt-\% $\mathrm{TiO}_{2}$, 2$6 \mathrm{wt}-\% \mathrm{Al}_{2} \mathrm{O}_{3}$ ); olivine show altered to Mg-rich talc or dolomite, calcite, and Fe-oxides; prismatic apatite; and Ti-magnetite. Both homogeneous and zoned phlogopite phenocrysts have been observed. The latter type has distinctive discrete, iron-rich (19-30 wt-\% FeO), aluminium depleted $\left(\mathrm{Al}_{2} \mathrm{O}_{3}\right.$ 6-10 wt-\%) annite rims. Euhedral to anhedral pseudomorphs after olivine are smainly mantled by phlogopite similar in composition to phenocrystal mica. Typical groundmass phases include major sanidine (FeO $<1$ wt-\%), dolomite, apatite, phlogopite-annite, Ti-magnetite, and Ti-oxide, which encloses monazite. Chlorite, talc, and zeolites has been observed. In general groundmass mica, when present, is similar to the rims of zoned phlogopite rims. Sanidine and dolomite \pm anatase \pm aegirine augite \pm quartz \pm calcite form leucocratic segregations, which show forms ranging from irregular patches with gradational boundaries to globular segregations and ocelli. Macrocrystal phases in the order of abundance include aluminous ( 10 wt-\% $\mathrm{Al}_{2} \mathrm{O}_{3}$ ) diopside lower in $\mathrm{MgO}$ and $\mathrm{SiO} 2$ relative to phenocrystal diopside, magnetite, Fe-oxide-phlogopite nodules, phlogopite, and annite.

Geochemistry

Eight of the analyzed dyke and boulder samples $(n=11)$ are ultrabasic (SiO2 41-45 wt-\%), ultrapotassic (cf. Foley et al., 1987) $\left(\mathrm{K}_{2} \mathrm{O} 3.4-8.3\right.$ wt-\%, molar $\mathrm{K}_{2} \mathrm{O}$ $/ \mathrm{Na}_{2} \mathrm{O}$ 3.0-21.0, MgO 9.6-15.6 wt-\%), and exhibit low $\mathrm{Al}_{2} \mathrm{O}_{3}$ relative to total alkalis (molar $\mathrm{K}_{2} \mathrm{O} / \mathrm{Na}_{2} \mathrm{O}$ 0.60.8, molar $\left(\mathrm{K}_{2} \mathrm{O} / \mathrm{Na}_{2} \mathrm{O}\right) / \mathrm{Al}_{2} \mathrm{O}_{3}$ 0.7-1.0). Three of the samples (D 10-12) are basic (SiO2 46-50 wt-\%) and otherwise similar to ultrabasic ones, but the most SiO2-rich sample, from dyke 12, is enriched in $\mathrm{Al}_{2} \mathrm{O}_{3}$ (16.9 wt-\%), $\mathrm{Na}_{2} \mathrm{O}$ (4.3 wt-\%) and depleted in $\mathrm{MgO}$, $\mathrm{TiO}_{2}$ (3.8 and 1.2 wt-\%, respectively), Cr, and $\mathrm{Ni}$ relative to the other samples. All samples are enriched in incompatible elements, for example, the ranges of Ba (3000-4800 ppm), Sr (1440-4100 ppm), La (140280 ppm), and Zr (750-1539 ppm).

\section{Discussion and conclusions}

The VUDS shows features typically associated with ultramafic lamprophyres, lamproites, and orangeites. The assemblage of abundant mica, diopside, and carbonate is common in ultramafic lamprophyres and orangeites, but not in lamproites. Absence of Ti-rich garnet in the dykes bear mineralogical evidence against classification as bona fide ultramafic lamprophyres (cf. Tappe et al. 2005). Lamproite affinity is exemplified by compositional data on mica phenocrysts that show mild depletion of $\mathrm{Al}$ and $\mathrm{Ti}$ enrichment towards the rims. In contrast, in some samples mica zoning shows Al depletion combined with $\mathrm{Fe}$ enrichment and $\sim$ constant $\mathrm{Ti}$ indicating an orangeite-like cooling history. The whole rock data of dyke 12 shows obvious contamination with crustal material. MgO (9.2-15.7 wt\%) of the dykes is fairly low relative to unevolved orangeites (Michell \& Bergman, 1991), but similar to average lamproites and evolved orangeites (Tainton, 1992). Concentrations of $\mathrm{Zr}$ (279-1515 ppm) and Nb (92-206 ppm) reflect affinities to olivine lamproites (eight of 11 samples), orangeites (two of 11 samples), and leucite lamproites (one of 11 samples) whereas all $\mathrm{Nb} / \mathrm{La}$ and $\mathrm{Ce} / \mathrm{Sr}$ ratios (0.44-1.01; 0.13-0.22, respectively) are more similar to orangeites (Taylor et al., 1994). Previously published Nd-Sr data (Luttinen et al., 2002) indicates radiogenic $\mathrm{Nd}$ atypical of ultramafic lamprophyres but typical of lamproites and orangeites. In summary, the dykes are best considered 
as members of the lamproite - orangeite suite; further studies on mineral chemistry, however, will be done as here we presented preliminary results on the mineralogy and geochemistry of VUDS.

\section{Acknowledgements}

We wish to thank FINNARP crews 1998, 2003, and 2007 for co-operation, and Mr. P. Heikkilä, Ms. T. Vaahtojärvi, Dr. R. Törnroos, Ms. H. Korkka (University of Helsinki), and Ms. M. Lehtonen (Geological Survey of Finland) for assistance with SEM, geochemical analyses, and sample preparation.

\section{References}

Corner, B., 1994. Geological evolution of western Dronning Maud Land within a Gondwana framework: Geophysics subprogramme. Final project report to SACAR. Department of Geophysics, Whitwaterstrand University, South Africa, 21 p.

Foley, S.F., Venturelli, G., Green, D.H., \& Toscani L., 1987. The ultrapotassic rocks: characteristics, classification, and constraints for petrogenetic models. Earth Science Reviews 24, 81-134.

Groenewald, P.B., Moyes,A.B., Grantham, G.H., and Krynauw, J.G., 1995. East Antarctic crustal evolution: geological constraints and modelling in western Dronning Maud Land. Precambrian Research 75, 231-250.

Jacobs J., Fanning C.M., Henjes-Kunst F., Olesch M., and Paech H., 1998. Continuation of the Mozambique belt into East Antarctica: Grenville-age Metamorphism and polyphase Pan-African highgrade events in central Dronning Maud Land. Journal of Geology 106, 385-406.

Lawver L.A., Gahagan L.M., \& Coffin M.F., 1992. The development of paleoseaways around Antarctica. In: The Antarctic paleoenvironment, a perspective on global change (eds. Kennett J.P. \& Warnke D.A.), pp. 7-30. Antarctic Research Series no: 56.

Luttinen A.V, Zhang X., and Foland K.A., 2002. 159Ma Kjakebeinet lamproites (Dronning Maud Land, Antarctica) and their implications for Gondwana breakup processes. Geological Magazine 139, 525-539.

Luttinen A.V., and Furnes H., 2000. Flood Basalts of Vestfjella: Jurassic Magmatism Across an Archean Proterotzoic Lithospheric Boundary in Dronning Maud Land, Antarctica. Journal of Petrology, 41, 1271-1305.

Mitchell R.H., 1995. Kimberlites, orangeites, and related rocks. Plenum Press, New York, 410 p.

Mitchell R.H., \& Bergman S.C., 1991. Petrology of lamproites, Plenum Press, New York, 441p.

Moyes, A. B., Krynauw, J. R. \& Barton, J. M., 1995. The age of the Ritscherflya Supergroup and Borgmassivet Intrusions, Dronning Maud Land, Antarctica. Antarctic Science, 7, 8797.

Riley,T. R., Leat, P.T., Curtis, M. L., Millar, I.L., Duncan, R.A., Fazel, A., 2005. Early-Middle Jurassic Dolerite Dykes from Western Dronning Maud Land (Antarctica): Identifying
Mantle Sources in the Karoo Large Igneous Province. Journal of Petrology, 46, 1489-1524.

Romu I., \& Luttinen A.V., 2007. Lamproite-hosted xenoliths of Vestfjella: Implications for lithospheric architecture in western Dronning Maud Land, Antarctica. In: Cooper A. and Raymond C. and the ISAES Editorial Team, 2007. Antarctica; A keystone in a changing world--online proceedings for the tenth international symposium on Antarctic earth sciences: U.S. Geological Survey Open-File Report 2007-1047

[http://pubs.usgs.gov/of/2007/1047/].

(DVD-ROM)

Tainton, K.M., 1992. The petrogenesis og Group-2 Kimberlites and Lamproites from the Northern Cape Province, South Africa. Un-published PhD thesis, St. John's College, Cambridge.

Tappe S., Foley, S.F., Jenner, G.A., and Kjarsgaard B.A., 2005. Integrating Ultramafic Lamprophyres into the IUGS Classification of Igneous Rocks: Rationale and Implications. Journal of Petrology 46, 1893-1900.

Taylor W.R., Tompkins, L.A., and Haggerty S.E., 1994. Comparative geochemistry of West African kimberlites: Evidence for a micaceous kimberlite endmember of sublithospheric origin. Geochimica et Cosmochimica Acta, 58, 4017-4037.

Vuori, S.K. and Luttinen, A.V., 2003. The Jurassic gabbroic intrusions of Utpostane and Muren: insights into Karoorelated plutonism in Dronning Maud Land, Antarctica. Antarctic Science, v.15 (2), 283-301.

Zhang, X., Luttinen A.V., Elliot D.H, Larsson K., and Foland, K.A., (2003), Early stages of Gondwana breakup: The 40Ar/39Ar geochronology of Jurassic basaltic rocks from western Dronning Maud Land, Antarctica, and implications for the timing of magmatic and hydrothermal events, Journal of Geophysical Research, 108(B9), 2449. 